\title{
Deus está morto? Considerações sobre fundamentalismo, fechamento identitário e violência na contemporaneidade
}

\author{
Is God dead? Considerations on fundamentalism, identitary \\ closure and violence in contemporaneity
}

DiOGO BOGÉA(Da

\section{Resumo}

Investigação do significado e dos principais desdobramentos da chamada "morte de Deus" em Nietzsche, a partir de uma leitura atenta dos três aforismos de $A$ Gaia Ciência que abordam mais claramente a questão, a saber: O homem louco, No horizonte infinito e Novas lutas. Caracteriza-se a morte de Deus como morte do absoluto incondicionado da metafísica. Diante deste diagnóstico, discutiremos o perigo de uma retomada nostálgica dos fundamentos absolutos. A partir dessas indicações, tentaremos pensar as diversas manifestações de fundamentalismos, fechamentos identitários e discursos violentos que circulam na contemporaneidade. Em nossas considerações finais, a preocupação não foi apresentar alguma "saída", mas insistir no aprofundamento da crise, no enfrentamento da angústia de viver num mundo "sem fundamentos" como passo necessário para o surgimento de novas possibilidades existenciais.

Palavras chave: Morte de Deus. Vontade de verdade. Fundamentalismo.

\section{Abstract}

Investigation on the meaning and the main consequences of the so called "God's death" from a careful reading of the three Gay Science's aphorisms which refer more clearly to it, that is: The insane man, The infinite horizon and New Fights. God's death is defined as the death of metaphysic's inconditional absolute. Facing this diagnosis, thare's the danger of a nostalgic recuperation of absolute grounds. From these indications, we'll try to think the many manifestations of fundamentalisms, identitary closures and dicursive violence circulating in contemporary times. In our final remarks, the concern was not to present a "solution", but to insist on the deepening of the

\footnotetext{
a Universidade do Estado do Rio de Janeiro (UERJ), Rio de Janeiro, RJ, Brasil. Doutor em Filosofia, e-mail: diogobogeaa@hotmail.com
} 
crisis, facing the anguish of living in a world with no grounds as a necessary step for the emergence of new existencial possibilities.

Keywords: God's Death. Will to truth. Fundamentalism.

\section{A morte de Deus}

“Deus está morto! Deus continua morto! E nós o matamos!” (NIETZSCHE, 2001, p. 147) Que pode significar esta emblemática e poderosa afirmação que Nietzsche deixa vir à luz através da fala do "homem louco" no aforismo 125 de $A$ Gaia Ciência? Num primeiro momento, numa primeira leitura, pode parecer apenas mais um dos ataques de Nietzsche ao cristianismo. Mais um daqueles momentos nos quais Nietzsche, vestindo a máscara do "anticristo", desfere outro duro golpe do seu martelo filosófico contra a entidade máxima do cristianismo, o Deus cristão. Com isso, então, a frase inicial poderia simplesmente querer dizer, fazendo coro com os ateus contemporâneos: “O Deus cristão não existe!”. Bom, uma leitura completa e atenta do aforismo deixa bem claro que não é disso que se trata. Não é esse o significado mais profundo da frase de Nietzsche.

Vejamos o aforismo completo. O aforismo se chama $O$ homem louco:

"Não ouviram falar daquele homem louco que em plena manhã acendeu uma lanterna e correu ao mercado, e pôs-se a gritar incessantemente: 'Procuro Deus! Procuro Deus!?” (NIETZSCHE, 2001, p. 147). Neste começo já se encontram ao menos três elementos bastante significativos para a compreensão do aforismo. Em primeiro lugar, chama a atenção o lugar onde o episódio se dá: o "mercado". Aqui é preciso que nos lembremos: a "praça do mercado" é nada menos que a Ágora, o lugar privilegiado do filosofar na antiguidade grega. Agora é o lugar por excelência da esfera pública ateniense. Ágora diz tanto o lugar da reunião, como a própria reunião dos homens que se unem para discutir questões públicas relativas ao âmbito sociopolítico. É o espaço de exercício da democracia ateniense, é o espaço, portanto, da palavra, da discussão argumentativa e do argumento fundamentado. E isso quer dizer: o espaço de desenvolvimento do logos. É na Ágora, na "praça do mercado" de Atenas, que 
Sócrates - figura que representa o próprio princípio da razão ocidental — vem interpelar os homens da cidade. Portanto, o cenário escolhido, o "mercado", que, como podemos imaginar, num século XIX industrial e capitalista só pode ser lugar de compra, venda e negociação, remete, na verdade, ao próprio princípio da Filosofia ocidental, ao espaço por excelência de desenvolvimento do logos, da razão, do diálogo socrático, e isso diz ainda: da valorização das essências eternas e imutáveis em detrimento das aparências mutáveis corruptíveis.

Em segundo lugar, vejamos: quem fala, sendo também aquele que dá título ao aforismo, é o homem louco. Ou seja, quem vem falar aos humanos no "mercado", buscando trazer à luz o que há de mais essencial no seu próprio tempo, quem vem trazer a verdade do tempo à multidão de humanos que passam desatentos, imersos em sua rotina, guiados por opiniões superficiais acerca do que se passa, é o homem lonco, ou seja, o homem que pensa de um modo tão radicalmente estranho à racionalidade tradicional estabelecida que foi dela excluído, posto à margem, estigmatizado como o indigno de atenção, como o insensato, como o que não fala "coisa com coisa", ou seja, o que escapa, em seu dizer, ao encadeamento argumentativo fundamentado, isto é, racional. O louco é, tradicionalmente, o que se opõe, ou simplesmente o que é essencialmente estranho à razão tradicional.

E em terceiro lugar, temos o curioso fato de homem louco sair "de manhã", com uma lanterna acesa, procurando por Deus. Esta passagem parece fazer alusão a um emblemático personagem da tradição filosófica antiga: Diógenes, o cínico — este, também, um tanto estranho à racionalidade tradicional, tanto é que foi definido por Platão como "um Sócrates demente" (LAÉRCIO, 2008, p. 165). Conta-se que Diógenes saía durante o dia com uma lanterna acesa procurando pelo homem. "Procuro pelo homem, procuro pelo homem!", ele dizia. Fala irônica em complemento ao irônico ato de sair com uma lanterna acesa em plena luz do sol. Diógenes "procurava" então por um humano verdadeiro, por um humano que vivesse segundo sua essência, ao invés de viver absorto por suas tarefas diárias, cultivando como objetivos máximos a riqueza e a fama e acumulando em torno de si objetos materiais e conteúdos espirituais inessenciais à sua vida. $\mathrm{O}$ homem louco procura por Deus. Mas, se o faz à maneira de Diógenes, procura por Deus em sua 
essência, procura por deus em sua verdade, mas não o encontra em parte alguma, não pode encontrá-lo, pois, como anunciará um pouco mais tarde, Deus, em sua essência, está morto. Assim, como Diógenes encontrava homens por toda parte, O homem louco encontrava Deus na palavra do crente, nas Igrejas, mas tanto nas Igrejas, quanto na palavra do crente, figuravam apenas aspectos inessenciais de Deus, uma simples imagem, um mero fantasma de um Deus que, em sua essência, está morto.

Continuemos com o aforismo:

E como lá se encontrassem muitos daqueles que não criam em Deus, ele despertou com isso uma grande gargalhada. Então ele está perdido? Perguntou um deles. Ele se perdeu como uma criança? Disse um outro. Está se escondendo? Ele tem medo de nós? Embarcou num navio? Emigrou? gritavam e riam uns para os outros. O homem louco se lançou para o meio deles e trespassou-os com seu olhar. "Para onde foi Deus?", gritou ele, "já Ihes direi! Nós o matamos - vocês e eu. Somos todos seus assassinos! Mas como fizemos isso? Como conseguimos beber inteiramente o mar? Quem nos deu a esponja para apagar o horizonte? Que fizemos nós ao desatar a terra do seu sol? Para onde se move ela agora? Para onde nos movemos nós? Para longe de todos os sóis? Não caímos continuamente? Para trás, para os lados, para a frente, em todas as direções? Existem ainda em 'cima' e 'embaixo'? Não vagamos como que através de um nada infinito? Não sentimos na pele o sopro do vácuo? Não se tornou ele mais frio? Não acontece eternamente? Não temos que acender lanternas de manhã? Não ouvimos o barulho dos coveiros a enterrar Deus? Não sentimos o cheiro da putrefação divina? - também os deuses apodrecem! Deus está morto! Deus continua morto! E nós o matamos!" (NIETZSCHE, 2001, p. 147-148).

Alguns dentre os presentes em cena, aqueles que não acreditam em Deus, desfazem-se em gargalhadas e põem-se a perguntar para onde terá ido Deus. Atravessa sua fala uma hipótese proferida em tom de riso: “terá Deus nos abandonado?”, “terá Deus se retirado do mundo deixando seus filhos entregues à sua própria sorte?". Mas, então, o homem louco responde, afastando essa hipótese e revelando a verdade para a qual mesmo aqueles que não acreditam em Deus não atentaram ainda: "Nós o matamos!", o homem louco diz, "vocês e eu! Somos todos seus assassinos!". Não se trata, portanto, de um ataque direto ao cristianismo ou à entidade "Deus cristão". O homem louco não está, tampouco, nos conclamando para mover guerra contra o Deus cristão, isto é: a morte de Deus em Nietzsche não é um projeto a ser realizado, um objetivo a ser cumprido através de um procedimento determinado. A morte de Deus é o que já se deu. A morte de Deus é o diagnóstico irremediável e irreversível de um fato fundamental que já se deu.

Na sequência percebemos que o alcance do diagnóstico "Deus está morto!" — o alcance deste assassinato fundamental — se estende para muito além do Deus específico de uma determinada religião - a religião cristã. Assassinar Deus 
corresponde a: 1. Beber inteiramente a água do mar. Esvaziar inteiramente o oceano. À custa de um penoso "beber" uma quantidade tal de água salgada que transcende em muito nossas reais capacidades, esvaziar a imensidão azul e imperturbável do oceano. Isso diz também: desvendar, pôr às claras o fundo do mais misterioso, do imperscrutável, do inexplorado inexplorável "fundo do mar", deixando ao final exposto seu fundo real: areia seca e infértil, deserto. 2. Apagar o horizonte com uma esponja. Mas o horizonte é o limite último que delimita nossa conformação espaçotemporal. A "linha" de um horizonte espacial ou temporal determina a medida da dimensão espaço-temporal na qual nos encontramos, delimita a amplitude do nosso campo de visão e de projeção, orienta nossa compreensão do mundo e configura nossas possibilidades de experiência deste mundo. (Para falar como Heidegger, por exemplo, é o horizonte compreensível inaugurado por uma determinada configuração epocal do Ser que determina nossa compreensão do Ser e, consequentemente, nossas possibilidades de experiência segundo esta mesma compreensão do Ser). 3. Desatar a terra do seu sol. Com o assassinato de Deus, desatamos a Terra do seu sol, e isso quer dizer: rompemos o laço entre o mundo da nossa experiência possível e o "absoluto", o "incondicionado", o fundamento último que iluminava nosso mundo a partir do além, derramando sobre nosso mundo a luminosidade absoluta da Verdade e do Bem. Lembremos que o "Sol" é a metáfora platônica para a ideia suprema de Bem, aquela que "é a causa de tudo o que de reto e belo existe em todas as coisas". No mundo visível, “ela engendrou a luz e o soberano da luz; no mundo inteligível, é ela que é soberana e dispõe a verdade e a inteligência; e é preciso vê-la para se comportar com sabedoria na vida particular e na vida pública" (PLATÃO, s/d, p. 271). Desatar a terra do seu sol é, portanto, romper os laços com o absoluto, com o incondicionado, com o fundamento último do mundo.

E Nietzsche se pergunta com o homem louco: "Como"? Como conseguimos beber inteiramente o mar? "Quem”? Quem nos deu a esponja para apagar o horizonte? Como e através de quem ou de que nós, os assassinos de Deus, logramos cometer o maior dos assassinatos da história ocidental? A prevalência atribuída à "verdade" em detrimento da "aparência", desde Platão e o mundo das ideias definido como mundo verdadeiro, passando pelo cristianismo — Deus é a verdade, a moral é a verdade e a 
tarefa suprema do humano é buscar a verdade, buscando a Deus e buscando a correção moral — pela filosofia e a ciência modernas - a certeza cartesiana como superior ao erro, a exatidão da ciência como valor superior - e chegando até a nossa era de máxima efetivação tecnocientífica, acaba por voltar-se contra o absoluto verdadeiro, agora relegado à categoria de um "mero ideal” sem valor efetivo.

Num fragmento póstumo do inverno de 1887, Nietzsche descreve o caminho trilhado pela moral ocidental — platônica, cristã, moderna —, que, enquanto exigência de verdade, acaba por voltar-se contra si mesma. "Entre as forças que a moral cultivou estava a veracidade. Esta se volta, por fim, contra a moral, descobre sua teleologia, sua consideração interessada" (NIETZSCHE, 1980, p. 211). É por volta dessa mesma época que na seção 3 de A genealogia da moral, Nietzsche se pergunta novamente pela causa da morte de Deus, se pergunta novamente "como" chegamos a conseguir beber inteiramente a água do mar, "quem" nos deu a esponja para apagar o horizonte? A resposta, que Nietzsche remete ao aforismo 357 de A Gaia Ciência é, mais uma vez, a "vontade de verdade", o cultivo da verdade do absoluto como valor superior que se faz presente em cada momento de nossa história:

O que, pergunta-se com o máximo rigor, venceu verdadeiramente o Deus cristão? A resposta está em minha Gaia Ciência, § 357: "A própria moralidade cristã, o conceito de veracidade entendido de modo sempre mais rigoroso, a sutileza confessional da consciência cristã, traduzida e sublimada em consciência científica, em asseio intelectual a qualquer preço" (NIETZSCHE, 2009, p. 138).

Nesta passagem, Nietzsche refere-se especificamente à morte de Deus enquanto Deus cristão. No entanto, como na leitura cuidadosa do aforismo 125 mostra-se claramente que a morte de Deus extrapola o âmbito da religião cristã, referindo-se ao absoluto metafísico em geral, pode-se estender também o alcance dessa história da "vontade de verdade", caracterizada pelo fato de trazer em si "o conceito de veracidade entendido de modo sempre mais rigoroso", à história ocidental desde o momento socrático-platônico até a era da máxima efetividade tecnocientífica em que se consuma, por fim, a morte de Deus enquanto morte do absoluto. Nossa era tecnocientífica chegou a um estágio tal de concretização da "vontade de verdade" que animou a história do pensamento ocidental até então, que nossa exigência hiperbólica de verdade chegou, por fim, a se voltar contra os ideais 
mais elevados que a humanidade alimentou — ou que alimentaram a humanidade até aqui. Diante da efetividade tecnocientífica Deus, o absoluto, o incondicionado não passam de ilusões, mentiras, tecnologias obsoletas de fundamentação.

Vemos, então, que o diagnóstico da morte de Deus não se restringe à figura do Deus cristão e nem sequer se restringe ao domínio da religião propriamente dito. Após se perguntar "Como" e "através de que ou de quem" se dá o assassinato em questão, Nietzsche se pergunta "Que fizemos nós?” ao matar Deus? Com isso, se coloca para nós a questão: Deus está morto, mas o que morre com Deus? E quais as consequências da morte de tudo aquilo que morre com Deus? Com Deus morrem todos os absolutos, com Deus morrem todos os valores que se pretendiam absolutos, com Deus morre tudo aquilo sobre o que nosso mundo repousava: a Verdade, o Bem, a Razão, o Sujeito. Com Deus morrem os próprios fundamentos de sustentação do nosso mundo. A morte de Deus é a morte do absoluto. Heidegger, na conferência “A sentença de Nietzsche 'Deus está morto"', compreende este sentido profundo que transborda a simples referência ao Deus cristão:

Deus é o nome para o âmbito das ideias e do ideal. Este âmbito suprassensível vige desde Platão, dito ainda mais precisamente, desde a interpretação grega tardia e cristã da filosofia platônica, enquanto o mundo verdadeiro e o propriamente real. Em contraposição a este, o mundo sensível é apenas o mundo do aquém, o mundo transitório e por isso mesmo aparente, irreal. O mundo do aquém é o vale das lamentações em contraposição à montanha da eterna bem-aventurança no além. Se denominarmos, como ainda acontece em Kant, o mundo sensível o mundo físico em sentido amplo, então o mundo suprassensível é o mundo metafísico. A sentença "Deus está morto" significa: o mundo suprassensível está sem força de atuação. Ele não fomenta mais vida alguma (HEIDEGGER, 2003, p. 478).

Sem o absoluto, o incondicionado, a segurança estável do fundamento último, ficamos sem parâmetros absolutos, seguros e estáveis para nos orientar: para onde se move a terra agora? "Para onde nos movemos nós? Para longe de todos os sóis? Não caímos continuamente? Para trás, para os lados, para a frente, em todas as direções? Existem ainda "em cima" e "embaixo"? Não vagamos como que através de um nada infinito? Não sentimos na pele o sopro do vácuo? Não se tornou ele mais frio? Não acontece eternamente?". Sem fundamentos, caímos e nem mesmo sabemos para onde caímos. Caímos em todas as direções. Não temos mais parâmetros seguros para nos orientar, não temos mais a estabilidade a partir da qual se determina nosso sentido. 
Vagamos através de um nada infinito sentindo na pele o sopro frio de um vácuo que acontece eternamente.

Será essa a palavra triunfante, o brado vitorioso de um dos assassinos de Deus? Será que está aberta, pela primeira vez para nós, a possibilidade de nos regojizarmos e dançarmos sobre o túmulo de Deus? Será que podemos, por fim, comemorar a compreensão de que "nada é verdadeiro, tudo é permitido" e passar nossos dias a festejar a liberdade de finalmente não termos absolutos, incondicionados e fundamentos seguros? Não é o que parece segundo o que se segue:

\begin{abstract}
Como nos consolar, a nós, assassinos entre os assassinos? 0 mais forte e mais sagrado que 0 mundo até então possuíra sangrou inteiro sob os nossos punhais? - quem nos limpará este sangue? Com que água poderíamos nos lavar? Que ritos expiatórios, que jogos sagrados teremos de inventar? A grandeza desse ato não é demasiado grande para nós? Não deveríamos nós mesmos nos tornar deuses, para ao menos parecer dignos dele? (NIETZSCHE, 2001, p. 148).
\end{abstract}

A nós, os assassinos de Deus, os assassinos do absoluto, não está aberta a possibilidade de simplesmente nos alegrarmos e dançarmos contentes sobre as ruínas dos antigos fundamentos que nos oprimiam e nos cerceavam, pois eram eles mesmos que também nos orientavam e nos guiavam e agora nos encontramos perdidos. A grandeza deste ato para o qual não estávamos ainda maduros agora nos oprime e nos desespera - o que esperar se não há parâmetros para indicar onde se pode depositar nossa esperança? Buscamos consolo, mas como nos consolar? Que ritos expiatórios, que jogos sagrados teremos de inventar? $\mathrm{E}$ isso quer dizer: como justificar o assassinato de Deus? Como lidar com a morte de Deus?

O absoluto fundamentava, sustentava, e isso quer dizer também, dava unidade e coesão ao nosso mundo. A referência fundamental ao absoluto reunia todos os seres sob uma ordem e uma coesão estabelecidas e sustentadas por ele próprio. Essa referência fundamental determinava também um sentido unívoco para a multiplicidade de seres existentes. Com a "morte" dos absolutos, morre também a referência fundamental provedora de unidade, coesão e sentido e o mundo se configura, então, como pura multiplicidade fragmentária, desordenada, caótica, da qual os absolutos não simplesmente se retiraram e desapareceram, mas também não reinam mais em seu posto supremo para além do mundo. Os absolutos permanecem no mundo enquanto mortos em putrefação, enquanto escombros e ruínas, enquanto 
simples partes integrantes da multiplicidade fragmentária e caótica que não faz nenhum "todo". Mas, com isso, chegamos a compreender a configuração do nosso mundo após a morte de Deus: vivemos num mundo de ruínas, de escombros, de dispersão, de multiplicidade fragmentária e caótica.

O assassinato de Deus pelos humanos da era tecnocientífica, o que quer dizer a morte do absoluto, é o acontecimento fundamental da nossa época, ele funda para nós uma época histórica. Vejamos a passagem seguinte do aforismo nietzschiano: "Nunca houve um ato maior - e quem vier depois de nós pertencerá, por causa desse ato a uma história mais elevada que toda a história até então!” (NIETZSCHE, 2001, p. 148). O maior dos atos da história ocidental até aqui — " "nunca houve um ato maior" - o assassinato de Deus por todos nós, humanos da era tecnocientífica, funda nossa época. Uma época em que o absoluto deixa de contar como absoluto em sua integridade magnificente e se estilhaça no campo relacional das multiplicidades fragmentárias efetivamente existentes.

Continuemos com a leitura da última parte do aforismo:

\begin{abstract}
Nesse momento silenciou o homem louco, e novamente olhou para seus ouvintes: também eles ficaram em silêncio, olhando espantados para ele. "Eu venho cedo demais", disse então, "não é ainda meu tempo. Esse acontecimento enorme está a caminho, ainda anda: não chegou ainda aos ouvidos dos homens. O raio e o trovão precisam de tempo, a luz das estrelas precisa de tempo, os atos, mesmo depois de feitos, precisam de tempo para serem vistos e ouvidos. Esse ato ainda lhes é mais distante que a longínqua constelação - e no entanto eles o cometeram! -Conta-se também que no mesmo dia o homem louco irrompeu em várias igrejas, e em cada uma entoou o seu Requiem aeternam dei. Levado para fora e interrogado, limitava-se a responder: "O que são ainda essas igrejas, se não os mausoléus e túmulos de Deus?" (NIETZSCHE, 2001, p. 148).
\end{abstract}

Diante do espanto e do silêncio dos ouvintes, o homem louco também silencia. Ele vem "cedo demais". O acontecimento do qual ele vem falar — o maior dos acontecimentos — ainda está a caminho, ainda "não chegou aos ouvidos dos homens". Os humanos não têm ainda olhos para ver e ouvidos para ouvir o acontecimento fundamental do seu tempo, aquele da morte de Deus e da destruição de todos os absolutos. "A luz das estrelas precisa de tempo", diz para si mesmo o homem louco. A maioria das estrelas que contemplamos no céu noturno já estão há muito tempo mortas, enquanto a luz de constelações inteiras estão ainda a caminho, viajam até nós sem que possamos ainda vê-las. O mesmo ocorre com os interlocutores do homem louco: contemplam ainda a luz do Deus já morto, não têm 
ainda olhos para ver a luz das novas estrelas que brilham na era inaugurada pela morte de Deus. Aqui ressoa a palavra do cínico homem louco: “Procuro por Deus!”. Por toda parte o homem louco encontra Deus. No entanto, onde está Deus em sua essência, onde está Deus em sua verdade, enquanto Deus assassinado, morto, para o qual as igrejas — outrora lugar de sua morada — se converteram em "mausoléus e túmulos"? Seus interlocutores ainda não têm ouvidos para o acontecimento fundamental que funda sua época.

\section{Fundamentalismo, fechamento identitário e violência}

O século XXI, herdeiro do acontecimento que funda nossa época histórica, vive um fenômeno aparentemente contraditório e paradoxal. Nos vemos imersos numa espécie de novo obscurantismo cultural em que os fundamentalismos retornam com força total. Digo contraditório e paradoxal porque justamente na era do ápice das realizações tecnocientíficas, na era da morte de Deus, da morte dos Absolutos, da morte dos fundamentos, vemos um recrudescimento das grandes narrativas antigas, um recrudescimento das religiões, um recrudescimento dos fanatismos políticos, o que resulta no reaparecimento de preconceitos que se julgavam estar há muito exterminados, na retomada de conflitos violentos que se julgavam estar há muito terminados. Somos cada vez mais envolvidos num clima de tomada de posição e defesa radical, ou melhor, fundamentalista, da posição adotada.

Questões religiosas típicas do cristianismo medieval tomam novamente um lugar central em nossas discussões, ganham espaço nas arenas políticas, que contam com a presença de uma "bancada religiosa", na grande mídia, nas instituições de ensino, nas redes sociais, que são hoje o nosso principal espaço de socialização. Discute-se até que ponto inovações tecnológicas e biomédicas violam ou não a vontade divina registrada nos textos sagrados. Discute-se até que ponto diferentes maneiras de exercício do pensamento, do gosto estético e da sexualidade violam ou não esta mesma vontade divina registrada nos textos sagrados. Discute-se até que ponto produções artísticas e culturais contrariam as leis divinas ferindo a imagem 
social dos seus fiéis. Retorna-se aos textos sagrados como lugar privilegiado da verdade histórica, epistemológica e, sobretudo, moral.

Ideologias políticas que se julgavam há muito decaídas e derrotadas retornam aos palanques dos debates sociopolíticos. Extremas esquerdas e extremas direitas disputam a verdade da memória, da história, da sociologia, do direito e da filosofia política. Proliferam nos grandes veículos de comunicação e nas redes sociais discussões anti-Marx e pró-Marx, antiliberais e pró-liberais, anticapitalistas e prócapitalistas, antitotalitarismo e pró-totalitarismo. Discute-se, numa configuração bipolar entre "esquerda" e "direita", qual foi, é e será a melhor forma de governo, a melhor forma de regime econômico e a melhor forma de organização social, sendo que "esquerda" e "direita" como classificações abstratas supostamente capazes de reunir sob uma mesma bandeira miríades de afetos e interesses diversos, não parecem dar conta da complexidade sociopolítica do nosso tempo.

No entanto, como a discussão — tanto religiosa quanto política ou sociocultural — se faz em termos fundamentalistas, cada um dos participantes já escolheu — ou já se deixou capturar — de antemão por um fundamento que, com pretensões de validade absoluta, sustenta, orienta, guia, fornece unidade e coesão embora nem sempre coerência - ao seu discurso. E num âmbito tal de discussão, não há realmente nenhuma discussão, não há diá-logo, mas monólogos que se contrapõem. Numa discussão pautada pela contraposição de monólogos, cada monólogo já assumiu sua posição fundamental e o debate se transforma em embate, em conflito de posições monolíticas que não admitem ceder um centímetro de terreno à outra, nem muito menos podem, nem uma nem outra, nem remotamente conceber a possibilidade de chegarem a alguma espécie de terceiro termo, fundado para além delas próprias na discussão, em que seus universos sejam ao menos minimamente compatíveis.

O debate vira combate, os pensantes e falantes que nele se engajam viram combatentes. Sua singularidade é diluída e conformada de acordo com um fundamento determinado. Tornam-se soldados a serviço de uma causa e cada vez que haja combate, estarão prontos para atacar o que é da ordem do Outro, do diferente, do estranho, do estrangeiro e defender o que é da ordem do "próprio", do "mesmo". 
$\mathrm{Na}$ ordem de uma tomada de posição fundamentalista, a discussão vira um jogo acusativo e defensivo, de ataque ao Outro e defesa do Mesmo. Opera-se no regime do "anti”, do "anti" contra "anti”, “anticristãos" contra "anti-ateus", “antiesquerdistas" contra "antidireitistas", e assim por diante. Resta impensado, no cerne de cada esquema argumentativo desta natureza que "enquanto um mero contramovimento, ele permanece porém necessariamente, preso, como todo 'anti-', à essência disso contra o que se volta” (HEIDEGGER, 2003, p. 479).

O Outro, o diferente, o estranho ao Si Mesmo determinado por um fundamento específico passa a ser visto como o inimigo. Já se tem dele, sem necessidade de que se procure conhecê-lo ou compreendê-lo de alguma forma, uma imagem negativa, uma pré-concepção a seu respeito. É então que vemos uma intensificação, junto com os fundamentalismos, dos preconceitos de toda ordem enraizados em nossas estruturas sociais. Proliferam nos espaços de socialização virtuais ou não - , preconceitos raciais, preconceitos de gênero, preconceitos quanto ao exercício da sexualidade, quanto ao poder aquisitivo, quanto ao gosto estético, quanto à identidade sociocultural. Preconceitos que se exercem cada vez mais frequentemente e cada vez mais intensamente em palavras e gestos ofensivos, discriminação, exclusão informal ou mesmo institucional.

Diante deste quadro geral, muitas pessoas todo o tempo "tomam posição", posicionam-se a todo momento "contra" isso ou "a favor" daquilo. Mas sua tomada de posição se dá pela mera reafirmação de uma posição preestabelecida na qual já se encontravam seguramente radicadas. Com isso, há por toda parte muita "opinião". Todos podem opinar e o fazem livremente, especialmente através do nosso espaço público de socialização por excelência — as redes sociais. Qualquer que seja a posição defendida, numa defesa em que vai necessariamente embutida, velada ou abertamente, um ataque ao Outro, há sempre a justificativa última que diz: "mas é a minha opinião". Mas a "opinião" de cada um já foi pré-moldada pela autoridade de um outro, pela autoridade do fundamento ao qual já aderiram numa tomada de posição fundamentalista. Ao remeterem seu dizer ao âmbito do que lhes é mais próprio e particular, a “sua própria opinião”, já se alienaram, alienando ao outro o poder de lhes 
moldar a opinião. No recurso ao que supostamente é o "mais próprio", na reapropriação mais própria do si mesmo em sua presença, já se deu, portanto a "expropriação", fazendo aqui um jogo com o vocabulário de Derrida, que pensa "a reapropriação como uma ex-propriação. "A re-apropriação produz necessariamente o contrário do que aparentemente ela visa” (DERRIDA; WEBER, 1992, p. 283).

A opinião, no que é moldada por um outro — pela autoridade do fundamento — já não pode apresentar suas razões de ser, já não procura pelos fundamentos de sua legitimidade, pois já foi moldada na forma preestabelecida por um fundamento previamente dado. Já não se vai ao fundo das questões, pois a investigação que vai ao fundo esbarra no fundamento previamente dado, este que, por seu caráter absolutista, ou seja, por se pretender absoluto, se põe como acima de qualquer questionamento e investigação. Mas se vivemos a era da morte dos fundamentos absolutos, os discursos que se pretendem absolutamente fundamentados caem no abismo do infundado e recaem na "opinião". De modo que se uma discussão procura insistentemente pelas razões de um argumento - isto quer dizer, se se põe em marcha uma investigação acerca da posição tomada - a resposta definitiva será “esta é a minha opinião". Isso significa que há muito pouca investigação e construção de conhecimentos que apresentem suas razões.

Com isso, a doxa prevalece, aplicando um contragolpe em relação à epistéme. Vivemos numa era de predomínio da doxa. E doxa aqui não diz mais somente discurso infundado, ilógico, que não apresenta suas razões de ser, mas discurso fundamentalista fundado por um fundamento que, na era da morte de Deus, só pode ser um fundamento infundado. $\mathrm{Na}$ era da morte dos fundamentos absolutos, o discurso que se pretende sustentar por um fundamento absoluto, se apresenta como infundado, ilógico e sem razão. E, no entanto, a relação epistéme-doxa ganha contornos irônicos se pensarmos que a requisição de fundamentação do discurso parte, em primeiro lugar, na história do pensamento ocidental, da própria epistéme, fazendo desta requisição de fundamentação justamente seu ponto de distinção em relação à doxa.

Mas doxa não diz apenas “opinião”. Numa etimologia filosófica da palavra, realizada por Heidegger em sua Introdução à Metafísica, doxa diz também “aparecer”, "mostrar-se", "entrar na luz", e, com isso, também "assumir um aspecto de 
consideração". "Doxa significa esse aspecto, qual seja, a consideração em que alguém se encontra. Caso o aspecto, de acordo com o que nele se apresenta seja extraordinário, doxa significa, então, glória e fama" (HEIDEGGER, 1999, p. 130). É no aparecer e assumir um aspecto de consideração que o ente que aparece se presta a ser encarado "deste ou daquele ponto de vista". Formam-se sobre ele diferentes "visões" e "muitas vezes tais visões se formam sem que examinemos cuidadosamente as coisas em si mesmas" (HEIDEGGER, 1999, p. 131). Assim surgem as diversas "opiniões" a seu respeito. Com esta análise mais profunda da palavra doxa, chegamos a compreender quão enredados estamos em sua teia. Nunca antes "aparecemos" e "nos mostramos" tanto. Estamos constantemente "expostos" à vista do público assumindo um "aspecto de consideração". Aquela "ditadura da opinião pública” (HEIDEGGER, 1974, p. 349) da qual Heidegger fala em Sobre o Humanismo não cessou de se intensificar e mesmo aquele quinhão de vida privada que Heidegger situa como simples contraposição ao público desaparece pouco a pouco na contemporaneidade. Estamos constantemente "ex-postos" ao público. As fronteiras entre "público" e "privado" tornam-se tênues, confusas e muitas vezes parecem prestes a desaparecer. Mesmo os aspectos mais particulares da nossa "vida privada" são expostos em postagens que atualizam constantemente nosso status corrente. A "fama" e a "glória" advindas dessa exposição duram apenas alguns minutos e são medidas pela quantidade de interações do "público" com a postagem que expõe nosso status atual.

Poderíamos hoje nos gabar por um feito inédito na história humana: a eliminação da solidão. Constantemente expostos ao público, nunca estamos sozinhos. Nem no escritório de estudos, nem no conforto noturno de nossas camas, nem numa viagem a um país longínquo. Estamos constantemente disponíveis. Não obstante, paradoxo ou consequência natural? - nunca antes o "antidepressivo" foi tão participante da vida corrente de uma época. Na cultura da ex-posição estamos constantemente postos — ou postados — para "fora" de nós mesmos. Com isso, deixamos cada vez menos espaço para entrarmos em contato com a angústia de viver num mundo sem fundamentos absolutos. Cada vez que a angústia rompe as barreiras do público e chega a nos incomodar, temos remédios diversos para aplacá-la 
instantaneamente. Mas é justamente a angústia fundamental, no que põe em questão todos os fundamentos estabelecidos, toda a doxa e toda a epistéme, que abre para nós a dimensão mais originária do pensamento.

\section{Considerações finais}

Decerto há muita opinião, pouco conhecimento, mas haverá em alguma parte ainda pensamento? Heidegger afirmou reiteradamente em seu texto chamado "O que chamamos pensar" que "o que há de mais problemático no nosso problemático tempo é que ainda não pensamos" (HEIDEGGER, 1997, p. 7). Somos "contra” ou “a favor”, tomamos posição, defendemos e atacamos, na tomada de posição nos expomos, mas em meio tantos embates e exposições, pensamos? Se a dimensão do pensar envolve o salto, o estar a caminho, o estar em transição que já não se encontra mais lá, mas também ainda não ali; se a dimensão do pensar envolve o risco de perder toda a segurança dos fundamentos pré-estabelecidos e se assim, aquele que pensa arrisca a si mesmo nesse risco; se a dimensão do pensar envolve ir até o fundo das questões e até o fundo do fundo das questões, o fundo que se põe para além de todos os fundamentos, de toda a segurança e estabilidade dos fundamentos, é possível, então, afirmar que pensamos?

Nestes fenômenos de retomada do fundamentalismo no século XXI, em que parece haver contradição e paradoxo, não há, na verdade, nenhuma contradição ou paradoxo. No aforismo 108 de A Gaia Ciência, intitulado Novas Lutas, Nietzsche diz: “Deus está morto; mas, tal como são os homens, durante séculos ainda haverá cavernas em que sua sombra será mostrada" (NIETZSCHE, 2001, p. 135). Deus está morto. Com Deus morreram todos os absolutos. O retorno fundamentalista ao fundamento nos indica uma das possibilidades — e um dos grandes perigos — da vida num mundo fragmentário: a reconstrução alucinatória de antigos fundamentos — religiosos e políticos - a partir dos seus destroços, resultando na construção de grandes palácios de sucata diante dos quais cada vez mais súditos, perdidos em meio às ruínas, se ajoelham, julgando ver neles a possibilidade impossível de uma salvação definitiva. Estes castelos de sucata, que se pretendem absolutos como se fossem ainda 
portadores da mesma glória do passado, são as "sombras de Deus", as sombras do absoluto morto que continuam a ser expostas nas paredes das cavernas do século XXI. Esse é o perigo da via nostálgica.

E Nietzsche diz "tal como são os homens", essas sombras ainda serão mostradas durante muitos séculos. Com a morte dos fundamentos antigos, os humanos são acometidos pela nostalgia do absoluto. Apegam-se às sombras do Deus morto como se estivessem diante do próprio Deus. E isso quer dizer: tomam posição, apegando-se a um fundamento que se pretende absoluto e engajam-se como bons soldados na defesa fundamentalista da sua causa. A crença na extrema esquerda, na extrema direita, no progresso histórico, na ciência como fonte de toda a verdade, a crença no próprio Deus da religião cristã, são fenômenos deste tipo. São exemplos de sombras que se oferecem em lugar do absoluto, são exemplos da reconstrução alucinatória de antigos fundamentos estilhaçados.

Alexandre Marques Cabral diagnostica com muita propriedade este retorno dos fundamentalismos no início de sua tese de doutorado "Niilismo e Hierofania", apontando para duas estratégias que parecem muito em voga atualmente na lida com o niilismo contemporâneo, isto é, na lida com o fenômeno global de desvalorização e dissolução de todos os valores absolutos que davam sustentação à tradição:

a estratégia nostálgica e a estratégia remoralizadora. Por vezes agindo de modo complementar e outras agindo autonomamente, estas estratégias têm em comum a intenção de corrigir o niilismo através do enfrentamento de seus efeitos. Não é raro escutarmos críticas incisivas ao mundo contemporâneo, não somente a partir de princípios vinculadores antigos, mas sobretudo em prol de sua rememoração, além da tentativa de sua reinstauração (CABRAL, 2011, p. 16).

\section{$\mathrm{Na}$ estratégia nostálgica}

o critério de avaliação do presente momento histórico emerge de uma medida histórica não mais presente, o que dificulta sua reatualização, porém, torna possível sua preservação enquanto ideal a ser desejado. [...] ela gera a sensação de que se pode acessar um critério válido para condenálo (CABRAL, 2011, p. 20).

Enquanto a estratégia "remoralizadora", que guarda um evidente parentesco com a primeira "se caracteriza por ser essencialmente terapêutica, pois sua proposta é curar o homem ocidental dos diversos males advindos do niilismo através da reativação dos valores morais e/ou religiosos sustentadores da civilização ocidental em tempos pregressos (CABRAL, 2011, p. 20)". 
Mas, então, que possibilidades alternativas de vida nos reserva um mundo fragmentário e caótico? Como vimos anteriormente, não se trata também daquela saída que se vê em certas interpretações que poderíamos chamar de "festivas": saída que consiste em simplesmente dançar sobre as ruínas, gozando uma liberdade absoluta em relação aos antigos valores. Um mundo em ruínas, um mundo de multiplicidades fragmentárias e caóticas não é simplesmente pura desorganização, pura desordem, pura "liquidez". Um mundo em ruínas é ainda um mundo permeado de configurações circunstanciais de poder que constituem intrincadas e complexas redes de relações de poder entre si. É ainda um mundo permeado por dominações, associações, negociações, hierarquias. Elas apenas não podem mais se dar como absolutas, mas sempre como relativas, temporárias, constantemente ameaçadas pela instabilidade e pela insegurança.

Para que possamos nos entregar ao pensamento de uma via alternativa à nostalgia, chamamos em nosso auxílio um terceiro aforismo de A Gaia Ciência intitulado No borizonte infinito:

Deixamos a terra firme e embarcamos! Queimamos a ponte - mais ainda, cortamos todo laço com a terra que ficou para trás! Agora tenha cautela, pequeno barco! Junto a você está o oceano, e é verdade que ele nem sempre ruge, e às vezes se estende como seda e ouro e devaneio de bondade. Mas virão momentos em que você perceberá que ele é infinito e que não há coisa mais terrível que a infinitude. Oh, pobre pássaro que se sentiu livre e que agora se bate nas paredes dessa gaiola! Ai de você, se for acometido de saudade da terra, como se lá tivesse havido mais liberdade -e já não existe mais "terra"! (NIETZSCHE, 2001, p. 147).

“Deixamos a terra firme e embarcamos!" Assassinamos Deus. Com ele morreram todos os absolutos. Apagamos o horizonte com a esponja da tecnociência e agora nos vemos à deriva, rodeados pelo horizonte infinito. Mas "não há coisa mais terrível que a infinitude" (NIETZSCHE, 2001, p. 147). A coisa mais terrível é a ausência de horizontes, de limites e princípios ordenadores estáveis. Porque o jogo não para. Continua havendo configurações de domínio, hierarquias, tensões, negociações, somos ainda chamados a tomar posição, mas faltam agora parâmetros absolutos que possam nos guiar. Tomados pela angústia de chamar por um absoluto que não vem, porque morreu, porque nós mesmos o assassinamos, somos acometidos de saudade da terra. Somos acometidos de saudade dos fundamentos antigos. Somos tomados pela nostalgia, esquecemos a opressão que o absoluto exercia sobre nós e 
somos envolvidos pela ilusão de que "aquele tempo" é que era bom, "como se lá tivesse havido mais liberdade! (NIETZSCHE, 2001, p. 147).

Mas, e então? Qual a saída? Procurando muito rapidamente por uma "saída", por uma "solução" definitiva, raciocinamos à maneira antiga, procurando na segurança de um fundamento absoluto qualquer uma "saída" e uma "solução". Tratase, talvez, de compreender com Nietzsche, que, uma vez que o barco já partiu Deus já está morto — “já não existe mais “terra”" (NIETZSCHE, 2001, p. 147) para onde voltar. Talvez, então, possamos tentar encarar a angústia e, a partir daí, quem sabe nos tornemos disponíveis para experimentar formas alternativas de vida num mundo "infinitamente" fragmentário e plural, um mundo que, querendo ou não, é o nosso.

\section{Referências}

CABRAL, A. M. Niilismo e bierofania: uma abordagem a partir do confronto entre Nietzsche e Heidegger. 778p. Orientador: Marco Antonio Casanova. Tese (Doutorado em Filosofia) - Universidade do Estado do Rio de Janeiro, Rio de Janeiro, 2011.

DERRIDA, J.; WEBER, E. Il faut bien manger ou le calcul du sujet. In: Points de suspension. Paris: Ed. Galilée, 1992. p. 269-300

HEIDEGGER, M. Introdução à Metafísica. Trad. Emanuel Carneiro Leão. Rio de Janeiro: Tempo Brasileiro, 1999

HEIDEGGER, M. O que chamamos pensar?'Trad. Edgar Tubingen. Lyra: Max Niemeyer, 1997. (a partir da $5^{a}$ edição integralmente revisada de Was heißt Denken?).

HEIDEGGER, M. Sobre o humanismo. Trad. Ernildo Stein. São Paulo: Abril Cultural, 1974.

HEIDEGGER, M. A sentença nietzschiana "Deus está morto". Trad. Marco Antônio Casanova. Natureza Humana, v. 5, n. 2, p. 471-526, jul./dez. 2003.

LAÉRCIO, D. Vida e doutrina dos filósofos ilustres. Trad. Mário da Gama Kury. Brasília: UNB, 2008

NIETZSCHE, F. A Gaia Ciência. Trad. Paulo César Souza. São Paulo: Companhia das Letras, 2001.

NIETZSCHE, F. Ecce Homo. Trad. Paulo César Souza. São Paulo: Companhia das Letras, 2008 
NIETZSCHE, F. A Genealogia da Moral. Trad. Paulo César Souza. São Paulo: Companhia das Letras, 2009.

NIETZSCHE, F. Kritische Studienausgabe (KSA). Org. Giorgio Colli e Mazzino Montinari. Berlin/New York. Walter de Gruyter, 1980.

PLATÃO. A República. Trad. Leonel Vallandro. Rio de Janeiro: Edições de Ouro, s/d. 